\title{
The Lisbon Agenda and Innovation-oriented Cohesion Policy: A New Challenge for Economic Integration among the EU Regions
}

\author{
Georg Wamser \\ University of Tuebingen, Tuebingen, Germany \\ Chang Woon Nam \\ Ifo Institute, Munich \& University of Applied Management, Erding, Germany
}

Alina Schoenberg

Bundeswehr University Munich, Neubiberg, Germany

\begin{abstract}
The EU's cohesion policy should now be confluent with the goals of the Lisbon strategy by promoting growth and employment. In this context the promotion of regional innovation systems has become important in the EU for guaranteeing long-term regional economic growth. This paper investigates the major determinants of varying degrees of innovation promotion from one region to another provided in the context of the EU's regional support program for the periods 2000 2006 and 2007 2013. While the new innovation-oriented policy appears to be incompatible with the goal of economic convergence among European regions, our research findings further question the consistency between the cohesion policy's objectives and its practice.
\end{abstract}

JEL Classifications: O18, O31, O52, R11, R58

Key Words: Lisbon Agenda, Regional Innovation Network, EU Cohesion Policy

\footnotetext{
* Corresponding Author: Georg Wamser; University of Tuebingen, Melanchthonstrasse 30, 72074 Tuebingen, Germany, Tel: +49 70712975423, Fax: +49 7071295590, E-mail: georg.wamser@uni-tuebingen.de.

Co-Author: Chang Woon Nam; Ifo Institute, Department of Public Finance, Poschinger Strasse 5, 81679 Munich \& University of Applied Management, Am Bahnhof 2, 85435 Erding, Germany, Tel: +49 8992241421, Fax: +49 89985369, E-mail: nam@ifo.de;

Alina Schoenberg; Bundeswehr University, Munich, Werner-Heisenberg-Weg 39, Neubiberg, Germany, Tel: +49 896004 4285, Fax: +49 8960044228, E-mail: alina.schoenberg@unibw.de.
} 


\section{Introduction}

According to Schumpeter (1934), the basic innovation carried out by firms provides the basis for long-term economic growth. The application of this idea in empirical regional science also suggests that regional growth is stimulated by the existence of numerous innovative industries and/or industries in the rapid-growth phase of the product life-cycle, and is retarded by the strong presence of old, declining industries. Moreover, the incidence of the introduction of new technology tends to be lower in those regions that are already economically disadvantaged (Grossman and Helpman, 1991). The Regional Innovation Performance Index, which testifies how spatially concentrated innovation activities are in 208 EU regions, suggests that innovative performance and economic development are closely linked in the EU regions (Hollanders, 2006; Fragerberg and Srholec, 2007). In this context, the promotion of regional innovation systems has recently become one of the important EU policy measures for guaranteeing the sustainable economic growth of a region: "generation, dissemination and use of knowledge [are] critical to the way in which businesses operate and grow. Facilitating access to finance and markets, promoting business support services, reinforcing links between enterprises and the scientific base, equipping people with the right skills through education and training, encouraging the take-up of new technologies and increasing investment in R\&D are all key to improving the business environment and stimulating innovation [as well as economic growth and job creation in the lagging EU regions]" (European Commission, 2004, p. 114).

Unlike the linear innovation-commercialization process which starts with basic scientific research and leads to the creation of a new product and its market introduction, chain-linked network characteristics have become crucial for the innovation and growth prospects of regions (Cooke and Memedovic, 2003; Yoon, 2004; Musyck and Reid, 2007). More precisely, innovation is seen as an evolutionary, systemic process resulting from various associational interactions among many actors in a given region (Puttnam, 1993; Nelson, 1993; Karlsson, 1995; Cooke 2001). A regional network usually comprises (i) horizontal and vertical relations among firms, (ii) the firms' contacts with universities and other research institutions, as well as with technology centers, and (iii) government agencies (promotion), interest groups (commercial, technical, and information support), and lending bodies (the provision of venture capital). The theoretical development of such a regional innovation system is based on the traditional concept of agglomeration economies and associated positive external effects (Glaeser, et al. 1992; Mills and McDonald, 1992; Zhang, 2007), and expanded further by integrating the logic of intangible social capital and its effects on regional growth. In short, regional innovation systems can be characterized as "places where close inter-firm communications, socio-cultural structures and institutional environment may stimulate socially and territorially embedded collective learning and continuous innovation" (Asheim and Isaksen, 2002, p. 83).

On the other hand, the knowledge-generation in regional innovation systems also has 
shortcomings: first, stable, long-lasting networks are assessed as prerequisites for innovation success, which could, however, impede the creation of new products due to the so-called path dependence (the 'lock-in-effects' shown in Fritsch, 2001; Cooke and Memedovic, 2003). 'Second, in a spatial sense, the 'closure'-aspect of the regional innovation process is emphasized, while at the same time the global exploitation of new opportunities appears to be crucial for the success of regional innovation systems (Amin and Thrift, 1994). Third, industrial clusters are usually defined by their local communities (Heidenreich, 2003), yet their performance is largely based on competition between firms in co-operation (Piore and Sabel, 1984).

The activation and utilization of endogenous innovation potentials for regional development has been a major challenge for innovation and technology-oriented regional policies. According to Koschatzky and Gundrum (1997), public (regional) technology and innovation promotion can ideally have three major tasks:

- activation of potential regional resources for the development and application of new technology,

- creation of a region-specific inter-linkage (i.e., the regional innovation network) that comprises all the relevant actors in industry, science, and policy, and

- integration of regional networks into supra-regional technology co-operation systems (see also Camagni, 1999; Courchene, 1995; Wolfe, 2002). ${ }^{2}$

Apart from the general critique, claiming that policy intervention disturbs free market mechanisms and allocation efficiency, and generates a culture of dependence, there are also some controversies on the extent to which the regional $R \& D$ promotion measures, which are aimed at supporting the establishment of innovative firms and research institutions in economically less-developed areas, reduce the existing disparities among regions. The effects of regional co-operation depend on the specific needs and the availability of partners that match these demands. Therefore, increasing the number of co-operative relationships (or the share of partners) within a region as well as supporting the formalization of local clusters alone cannot always be recommended as the best possible strategy (Grabher and Stark, 1997). As has already been mentioned above, regional innovation systems tend to be path-dependent. Due to this reason, if a region is dominated by declining industries or agricultural production, radical

\footnotetext{
Innovation and technological development in a region is path-dependent in the sense that a further step in the process is based on knowledge previously acquired or generated in the same region. "On the other hand, previous investments, competence, habits and qualifications are devalued by innovations. The benefits of innovations and the risks of omitted innovations, therefore, always have to be balanced against the costs of successful innovations and the benefits of omitted innovations" (Heidenreich, 2003, p. 502).

${ }^{2}$ Maurseth and Verspagen (2002), and Hoekman et al. (2009) additionally highlight that in the EU the volume of patenting in a region is greatly stimulated not only by the indigenous science-base and the funding of research, but also by the region's proximity to other regions with strong scientific performance. Furthermore, they argue that researchers collaborate most with each other in researchintensive regions, but that cross-border links tend to be far better established between researchers located in capital and other large city regions. These facts suggest that the three (regional, national, and international) levels of an innovation system do not function independently of each other, but mutually rely on each other's strengths and specific system qualities in order to productively interact (FromfoldEisebith, 2007).
} 
government intervention may be required to modernize its economic structure (Braczyk and Heidenreich, 1998; Turpin and Garrett-Jones, 2002).

More importantly, compared to the case of growth poles (i.e., the case of large city regions), innovation-oriented regional policy measures designed to stimulate the rapid establishment of regional technology networks (incl. the establishment of new innovative small and mediumsized enterprises - $\mathrm{SMEs}^{3}$ ) in less-developed (peripheral rural) areas have remained less successful, because in many cases they lack a sufficient mass of know-how, skills, finance, sociocultural and institutional infrastructure, and a certain degree of entrepreneurial tradition, which cannot easily be generated by public intervention within a short period of time (Amin and Thrift, 1994; Sternberg, 1995; Grotz and Braun, 1997; Cooke and Morgan, 1998; Melloni and Palmieri, 2011). However, growth poles in Europe have benefited from (national and regional) innovation promotion measures.

In the Treaty of Establishing the European Community, economic and social cohesion is defined in terms of reducing regional disparities in the level of development, usually measured by GDP per capita (relative to the EU average) in purchasing power parities (see also Karras, 1997; Yin and Zestos, 2003). ${ }^{4}$ As a timely response to slow economic growth in the EU, the Lisbon Agenda agreed to by EU leaders at the Lisbon summit in March 2000 aims at making the EU a more competitive and dynamic knowledge-based economy, capable of sustainable economic growth with more and better jobs and greater social cohesion. ${ }^{5}$ In other words cohesion policy should now be confluent with the goals of the Lisbon strategy by promoting growth and employment. In part, this political idea has been generated since there has been little clear consensus on the impact of 'past' EU cohesion policy on the economic growth of EU regions and convergence in the EU (Leonardi, 2006). Consequently, compared to the previous EU financial supports from Structural Funds which used to be concentrated on infrastructure and human capital development, the Lisbon strategy's stress on the knowledge economy raised new

\footnotetext{
Apart from the fact that SMEs suffer particularly from rapid technological development processes and the consequent organizational changes, it is generally assumed that the strong 'locational dependency' of small firms leads to 'bounded vision' including a lack of awareness of innovation possibilities caused by limited resource and knowledge bases, expertise, etc. (Wiig and Wood, 1997; Nauwelaers and Wintjes, 2000; Belussi, 2001). However, Pavitt, Robson, and Townsend (1987) suggest that small firms have also been able to introduce new products over time. Moreover, Rothwell (1986) emphasizes that SMEs are important agents in technology diffusion in that they take innovations made elsewhere and present them in various forms in ways that meets customers' needs. In many cases they are fast adopters of new technologies. Therefore, small and innovative firms are often seen as a potentially powerful force in local economic change (Wynarczyk, Thwaites, and Wynarczyk, 1997). However, there are also some disputes surrounding the technology promotion of SMEs as a long-term strategy for solving regional economic problems. Leaving aside the high insolvency rates among SMEs, large firm size is generally acknowledged as a prerequisite for technological change and economic progress (Gray, 1992). Large internationallyactive companies have a greater ability to provide capital, information, and experts. They can also spread innovation risks over a number of $R \& D$ projects.

${ }^{4}$ EU cohesion policy was originally designed to implement measures which would boost economic growth in the less-favored EU regions, thereby reducing the gap in their respective levels of development.

${ }^{5}$ In particular, it was agreed that to achieve this goal, an overall strategy should be applied, aimed at (a) preparing for the transition to a knowledge-based economy and society by better policies for information society and R\&D, as well as by stepping up the process of structural reform for competitiveness and innovation and by completing the internal market; (b) modernizing the European social model, investing in people, and combating social exclusion; and (c) sustaining a healthy economic outlook and favorable growth prospects by applying an appropriate macro-economic policy mix (see http://www.euractiv.com/future-eu/lisbon-agenda/article-117510).
} 
policy orientations for the EU cohesion policy. In particular, the role of regional innovation systems is seen as a kind of self-help and learning tool that is expected to trigger local, selfsustained growth dynamics, especially targeted at peripheral regions, which would, in turn, help these less-favored regions to catch up with core regions (De Bruijn and Lagendijk, 2005).

However, the integration of the Lisbon strategy in the EU regional policy has created some tensions between competitiveness aims and cohesion aspirations. According to Lawton-Smith (2003), the twin goals of increasing competitiveness in the global economy and economic and social convergence are contradictory and inherently comprise different policy options: the former is generally concerned with 'winners and losers', while the other is concerned with 'redistribution'. First of all, there is a trade-off between growth and cohesion, as different core and periphery growth trends tend to increase regional disparities at low levels of development. Secondly, while cohesion policy primarily aims at enabling low performing regions to catch up the core regions of the EU, the promotion of competitiveness triggered by the Lisbon Agenda seems to strengthen the competitiveness of the best performing regions. Furthermore, cohesion policy has primarily been bottom-up in the design and implementation of policy since 1989, and has had a regional dimension and a multi-level governance structure to accommodate it. In contrast, the Lisbon Agenda was imposed top-down on EU members with targets that are more macro- than micro-economic, and therefore has an overriding national dimension and clearly violates the subsidiarity principle (see also De Propris, 2007).

As has already been mentioned above, the EU's cohesion policy should now be confluent with the goals of the Lisbon strategy by promoting growth and employment. In this context, the promotion of regional innovation systems has recently become important in the EU for guaranteeing long-term regional economic growth. This paper attempts to explain the determinants of the varying degrees of innovation promotion by the EU from one region to another. Since regional-policy strategies should have been subject to a new orientation towards more innovation promotion, we are particularly interested in whether the EU's co-financing policy of innovation projects changed for the 2007 2013 program period compared with the 2000 2006 period.

Our empirical investigation gives rise to four main results. First, after conditioning on a number of aspects determining innovation promotion, we cannot confirm any increase in the degree of innovation promotion in the second program period of 2007 to 2013 (during which the new policy strategy should show up) compared with the first program period from 2000 to 2006. Second, when focusing on less-developed regions, innovation promotion for 2007 2013 has not been increased in Objective 1 regions $^{7}$ - which obtain a significantly higher level of innovation promotion overall compared with the earlier program period of 2000 2006. These

\footnotetext{
${ }^{6}$ According to the well-known subsidiarity principle, efficiency in the allocation of financial resources is best achieved by assigning responsibility for each type of expenditure to the level of government that most closely represents the beneficiaries of provided public goods and services. In other words, expenditure assignments involve decisions as to which level of government should be predominantly responsible for the formulation, financing, and administration of policy activities and related follow-ups.

${ }^{7}$ Objective 1 seeks to promote the development and adjustment of regions whose development is lagging behind - defined as those areas with a gross domestic product (GDP) of less than $75 \%$ of the EU average expressed in terms of purchasing power parities.
} 
first two findings are central and demonstrate that there has not been a considerable realignment of the EU's policy towards more innovation funding. Third, the analysis of the innovationspending-to-total-spending ratio shows that core regions with advanced economic performance obtain a relatively higher share of innovation spending. Fourth, the analysis of the level of innovation spending shows that more financing is provided to less-developed regions, which is in line with the basic policy goals of the EU's cohesion policy.

The paper is structured as follows. Section 2 provides an overview of innovation promotion in the context of the EU cohesion policy and also includes a case study of Spanish regions, comparing innovation promotion in different EU cohesion policy program years. Section 3 presents the data used for the analysis exploring the determinants of innovation spending and the regression results. In Section 4, we provide some concluding remarks.

\section{Innovation Promotion in the Context of EU Cohesion Policy}

\section{A. An Overview}

The policy priority of promoting regional innovation systems has been reflected for the first time in the cohesion policy program for the period of 2007 2013 addressed to the EU27. According to the overall EU financial budget, the main fields of investment and their relative shares of funding are classified into: (a) knowledge and innovation: almost 83 billion euros (24\% of the total 347 billion euros) are spent on research centers and infrastructure, technology transfer and innovation in firms, and the development and diffusion of information and communication technologies; (b) transport: about 76 billion euros (22\%) have been allocated to improving the accessibility of regions, supporting trans-European networks, and investing in environmentally sustainable transport facilities in urban areas in particular; (c) environmental protection and risk prevention: investments of around 51 billion euros (19\%) to finance water and wastetreatment infrastructures, decontamination of land in order to prepare it for new economic use, and protection against environmental risks; and (d) human resources: around 76 billion euros $(22 \%)$ are spent on education, training, employment, and social inclusion schemes. Other interventions concern the promotion of entrepreneurship, energy networks and efficiency, urban and rural regeneration, tourism, culture, and strengthening the institutional capacity of public administrations (Table 1).

Compared to the cohesion policy budget for the 2000 2006 period of 234 billion euros, Table 1 indicates that: (a) the financial share dedicated to promoting less-favorable EU regions increased from $75 \%$ to $82 \%$ in the course of EU expansion from 15 to 27 countries; (b) infrastructure support has also gained importance and has been increased from $32 \%$ to $37 \%$; (c) yet the share for promoting education and training has been reduced remarkably from $31 \%$ to $22 \%$; 
and (d) a movement of financial priority took place from the promotion of firms' production and cooperation activities including establishment and innovation (EU budget 2000 2006) to knowledge-innovation (EU budget 2007 2013).

Table 1. EU Budget for Cohesion Policy

\begin{tabular}{l|c|c}
\hline & $\begin{array}{c}\text { EU budget 2000 2006 } \\
\text { EU15 ( }+ \text { EU10 later) }\end{array}$ & $\begin{array}{c}\text { EU budget 2007 2013 } \\
\text { EU27 }\end{array}$ \\
\hline $\begin{array}{l}\text { Total amount } \\
\text { Promotion of Objective 1 (or Cohesion) region }\end{array}$ & $\begin{array}{c}234 \text { billion } €(100 \%) \\
175 \text { billion } €(75 \%)\end{array}$ & $\begin{array}{c}347 \text { billion } €(100 \%) \\
283 \text { billion } €(82 \%)\end{array}$ \\
\hline $\begin{array}{l}\text { Infrastructure } \\
\text { (mainly transport \& environment) }\end{array}$ & 76 billion $€(32 \%)$ & 127 billion $€(37 \%)$ \\
\hline $\begin{array}{l}\text { Firms' production \& cooperation activities } \\
\text { (incl. establishment \& innovation) }\end{array}$ & 73 billion $€(31 \%)$ & \\
\hline Human resources & 73 billion $€(31 \%)$ & 76 billion $€(22 \%)$ \\
\hline Knowledge-innovation & & 83 billion $€(24 \%)$ \\
\hline Cross-border cooperation \& others & 12 billion $€(5 \%)$ & 61 billion $€(18 \%)$ \\
\hline
\end{tabular}

(Source) European Commission (2008).

Let us now look at the EU cohesion policy operational programs officially adopted by the European Commission at the beginning of the budget years. For such programs, the total cost of regional programs and the respective EU contributions are reported at the NUTS 2 level. These programs were prepared by each EU member state and present the weights of financial priorities (e.g., infrastructure, innovation, human capital, environment, etc.) set by the national and regional authorities for the corresponding budget period. We are interested in the share of innovation promotion grants that are directly addressed to respective regions as well as the respective level of innovation promotion. We calculate the former variable as the national and EU sum of innovation support divided by the total cost of the regional program for an eligible region. ${ }^{9}$ The data is available at a NUTS 2 level for the EU program periods 2000 2006 and 2007 2013, respectively.

Figure 1 graphically highlights the difference between the two aforementioned program

\footnotetext{
${ }^{8}$ The NUTS classification (Nomenclature of territorial units for statistics) is a hierarchical system for dividing up the economic territory of the EU. The NUTS 2 level comprises basic regions for the application of EU regional policies. The EU cohesion policy operational programs also include national and multi-regional as well as cross-border regional cooperation programs (Ingiani and Zdarek, 2009). Yet, for such programs, the distribution of project costs from one region to another is unclear (see also http://ec.europa.eu/regional_policy/country/prordn/index_en.cfm).

${ }^{9}$ The EU only provides money for regional projects if national authorities also chip in. Such a 'matching co-finance principle' aims at ensuring a complementary relationship between the fund providers in the context of the EU cohesion policy (Nam and Wamser, 2010).
} 
periods. It shows simple box plots in which the upper one refers to the share of innovation spending out of the total spending of the 2000 2006 period and the lower box plot to that of the 2007 2013 period. According to Figure 1, the average share of EU innovation promotion for the 2007 2013 period is higher by a factor of 2.35 compared to that of the previous program period (0.372 vs. 0.158$)$.

Since the Lisbon Agenda particularly aimed at promoting the economic growth of Objective 1 regions in order to trigger catching-up processes, it appears to be interesting to display box plots for such regions separately. While innovation promotion was rather irrelevant in these types of regions during the 2000 2006 EU regional program, it has become more important in the latter program period. Figure 2 clearly demonstrates that the Objective 1 regions caught up in comparison to the regions not classified as Objective 1. Indeed, while it seems that the EU support shares for innovation activities in the EU regions have generally gone up, they particularly increased for the Objective 1 regions. Note that we will test in Section 3.B whether this descriptive fact still holds in a multivariate analysis.

Figure 1. Dispersion of the Share of Innovation Spending for EU Regions in Different Budget Periods

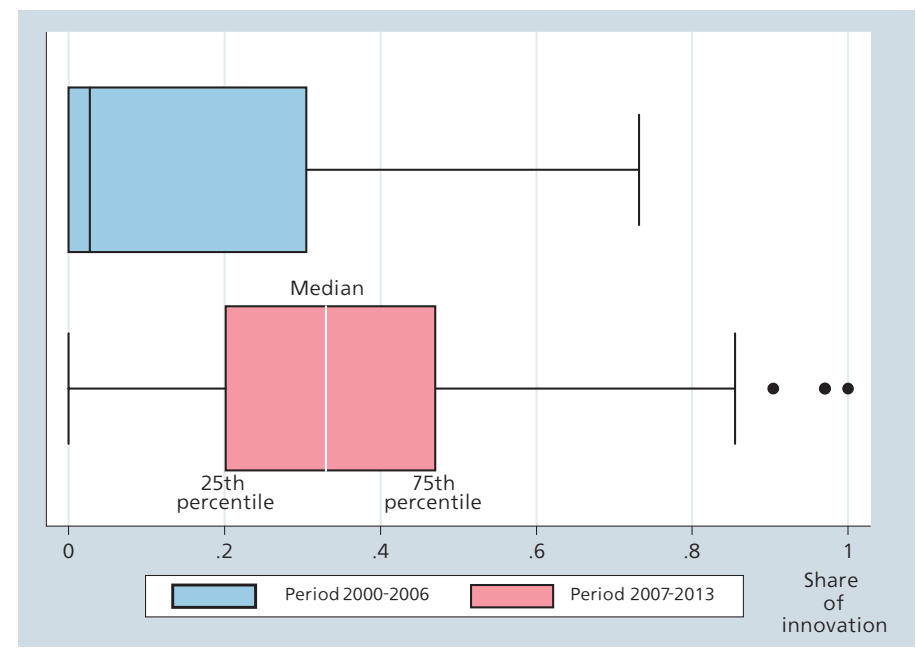

(Note) Share of innovation is measured as the amount of innovation promotion dedicated to a region divided by the total amount of contributions to a region.

(Source) Authors' calculation. 
Figure 2. Dispersion of the Share of Innovation Spending for EU Regions

(Distinguishing Objective 1 Regions from other Regions)

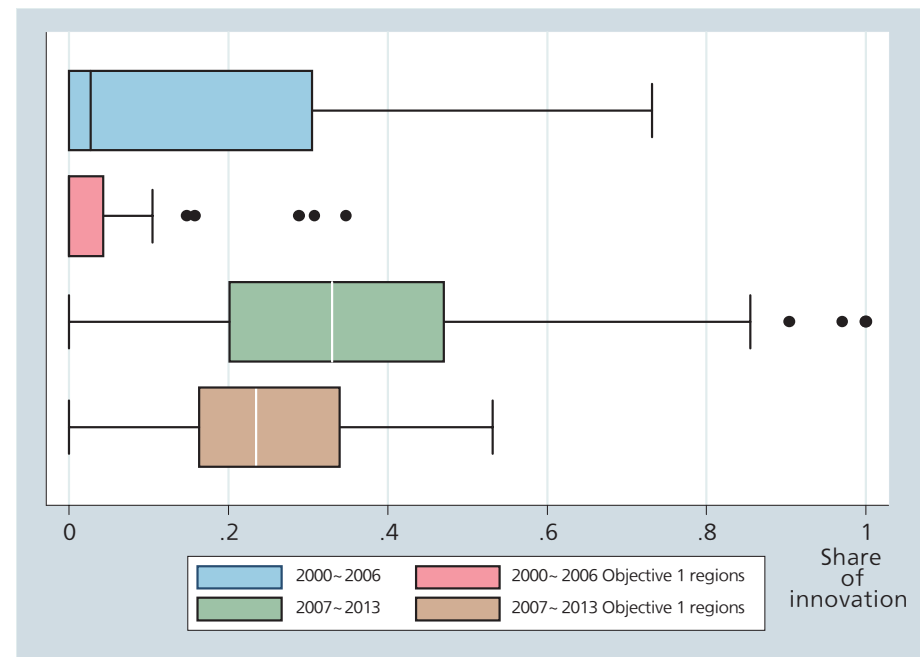

(Note) Share of innovation is measured as the amount of innovation promotion dedicated to a region divided by the total amount of contributions to a region.

(Source) Authors' calculation.

\section{B. Case Study: Comparison of Innovation Promotion in Spanish Regions}

The innovation promotion scheme implemented in the EU cohesion policy framework can be classified into the three categories: (a) financial support for firms' innovation activities, (b) promotion of public R\&D capacity expansion (universities and technology centers), and (c) support for projects aimed at the creation and (better) establishment of regional innovation system (i.e., cluster formation, networking, and knowledge transfers).

In the following, taking the Spanish regions as an example, the change of innovation policy practice is investigated between the EU program years of 2000 2006 and 2007 2013 to highlight the significance of the Lisbon Agenda for the cohesion policy in the EU regions. For the budget period of 2000 2006, Table 2 shows that firms' innovation activity was rarely promoted by the EU cohesion policy in the Spanish Objective 1 regions (except Valencia and Cantabria), while the same activity was financially supported in more advanced regions like Basque Country, Catalonia, Navarre, Aragon, etc. In contrast, the expansion of public R\&D capacity was generally promoted by the cohesion policy in most Spanish regions (except a few Objective 1 regions like Ceuta, Melilla, and Cantabria), in part in the context of the enhancement of infrastructure. The promotion of system-oriented, cluster formation, networking, and knowledge transfers was widespread only in the non-Objective 1 regions, while such a promotion did not 
exist at all in most less-favored Spanish regions in the 2000 2006 program period.

Compared to that of the former period, the 2007 2013 cohesion policy program delivers a quite different picture. First of all, regardless of the level of economic development, innovation and $R \& D$ activities are financially promoted in all Spanish regions. In particular, SMEs are major beneficiaries in most Objective 1 regions (except Murcia, Asturias, Ceuta, and Cantabria). For most Spanish regions, the enhancement of public R\&D capacity has been continuously playing an important role in the context of the EU cohesion policy, while an intensive promotion of cluster, networking, and knowledge transfer has also become apparent in most Objective 1 regions (Table 2).

In addition, one should also pay attention to the changes of innovation promotion as a \% - share of the total public (national and EU) contributions made within the EU cohesion policy framework (see columns 5 and 9, Table 2). The following observations can be made: firstly, in all the investigated Spanish regions the share of innovation promotion has rapidly grown from the former to the latter program period. Yet the extent of this increase has been much greater in the non-Objective 1 regions. Consequently, compared to that of the Objective 1 regions, the share of innovation promotion has generally remained much higher in the advanced regions during the two program periods. In other words, compared to the case in the less-favored regions, innovation promotion has been more strongly intensified in the rich regions in the program period of 2007 2013. These findings violate the basic idea of the new EU cohesion policy, which particularly aims at stimulating the catching-up process of the less-favored regions through the activation of innovation potential and the creation of a wellfunctioning innovation system in these regions. Furthermore, significant differences in the share of innovation promotion exist even within the group of Objective 1 regions, which has also become more apparent for the program period of 2007 2013. For example, the promotion share ranges widely from $16.3 \%$ (Canary Islands) to $41.0 \%$ (Valencia) and $79.8 \%$ (Cantabria). Hence, a more thorough investigation on the determinants of the share of innovation promotion appears to be necessary in order to explain its regional differences and to examine whether the objectives and the practices of the innovation-oriented EU cohesion policy are consistent. 
Table 2. Innovation Promotion in Spanish Regions in the Context of EU Cohesion Policy

\begin{tabular}{|c|c|c|c|c|c|c|c|c|}
\hline \multirow{3}{*}{ Region } & \multicolumn{4}{|c|}{ Budget year 2000 2006 } & \multicolumn{4}{|c|}{ Budget year 2007 2013} \\
\hline & \multirow{2}{*}{$\begin{array}{l}\text { Firm-oriented } \\
\text { promotion }\end{array}$} & \multicolumn{2}{|c|}{ System-oriented promotion } & \multirow{2}{*}{$\begin{array}{c}\text { Innovation } \\
\text { promotion as a } \\
\% \text {-share of total } \\
\text { public } \\
\text { contributions** }\end{array}$} & \multirow{2}{*}{$\begin{array}{l}\text { Firm-oriented } \\
\text { promotion }\end{array}$} & \multicolumn{2}{|c|}{ System-oriented promotion } & \multirow{2}{*}{$\begin{array}{c}\text { Innovation } \\
\text { promotion } \\
\text { as a } \% \text {-share of } \\
\text { total public } \\
\text { contributions*** }\end{array}$} \\
\hline & & \begin{tabular}{|c} 
Expansion \\
of public \\
$\mathrm{R} \& \mathrm{D}$ \\
capacity
\end{tabular} & $\begin{array}{c}\text { Promotion } \\
\text { of cluster, } \\
\text { networking, } \\
\text { and knowledge } \\
\text { transfer }\end{array}$ & & & $\begin{array}{c}\text { Expansion } \\
\text { of public } \\
\text { R\&D } \\
\text { capacity }\end{array}$ & $\begin{array}{c}\text { Promotion } \\
\text { of cluster, } \\
\text { networking, } \\
\text { and knowledge } \\
\text { transfer }\end{array}$ & \\
\hline Castile-La Mancha* & & $\mathrm{x}$ & & 1.9 & $\mathrm{x}^{* *}$ & $\mathrm{x}$ & $\mathrm{x}$ & 25.7 \\
\hline Canary Islands* & & $\mathrm{x}$ & & 4.2 & $\mathrm{x}^{* *}$ & $\mathrm{x}$ & $\mathrm{x}$ & 16.3 \\
\hline Castilla y Léon* & & $\mathrm{x}$ & & 2.7 & $\mathrm{x}^{* *}$ & $\mathrm{x}$ & $\mathrm{x}$ & 36.3 \\
\hline Extremadura* & & $\mathrm{x}$ & & 4.4 & $\mathrm{x}^{* *}$ & $\mathrm{x}$ & $\mathrm{x}$ & 23.5 \\
\hline Murcia* & & $\mathrm{x}$ & & 3.4 & $\mathrm{x}$ & $\mathrm{x}$ & & 30.8 \\
\hline Asturias* & & $\mathrm{x}$ & & 2.2 & $\mathrm{x}$ & $\mathrm{x}$ & & 35.2 \\
\hline Ceuta* & & & & 0.0 & $\mathrm{x}$ & & $\mathrm{x}$ & 16.9 \\
\hline Melilla* & & & & 0.0 & $\mathrm{x}^{* *}$ & $\mathrm{x}$ & $\mathrm{x}$ & 20.3 \\
\hline La Rioja & $\mathrm{x}$ & $\mathrm{x}$ & $\mathrm{x}$ & 26.7 & $x^{* *}$ & & $\mathrm{x}$ & 80.0 \\
\hline Andalusia* & & $\mathrm{x}$ & & 3.0 & $\mathrm{x}^{* *}$ & $\mathrm{x}$ & $\mathrm{x}$ & 27.2 \\
\hline Valencia* & $\mathrm{x}$ & $\mathrm{x}$ & $\mathrm{x}$ & 9.3 & $\mathrm{x}^{* *}$ & & & 41.0 \\
\hline Galicia* & & $\mathrm{x}$ & & 14.7 & $\mathrm{x}^{* *}$ & $\mathrm{x}$ & $\mathrm{x}$ & 24.7 \\
\hline Basque Country & $\mathrm{x}$ & $\mathrm{x}$ & $\mathrm{x}$ & 32.7 & $\mathrm{x}$ & & $\mathrm{x}$ & 72.0 \\
\hline Catalonia & $\mathrm{x}$ & $\mathrm{x}$ & $\mathrm{x}$ & 29.5 & $\mathrm{x}$ & $\mathrm{x}$ & $\mathrm{x}$ & 51.6 \\
\hline Navarre & $\mathrm{x}$ & $\mathrm{x}$ & $\mathrm{x}$ & 42.1 & $\mathrm{x}$ & $\mathrm{x}$ & $\mathrm{x}$ & 90.4 \\
\hline Aragon & $\mathrm{x}$ & $\mathrm{x}$ & $\mathrm{x}$ & 33.9 & $x^{* *}$ & $\mathrm{x}$ & $\mathrm{x}$ & 81.0 \\
\hline Balearic Islands & $\mathrm{x}$ & $\mathrm{x}$ & $\mathrm{x}$ & 26.9 & $\mathrm{x}$ & $\mathrm{x}$ & $\mathrm{x}$ & 56.2 \\
\hline Madrid & & $\mathrm{x}$ & $\mathrm{x}$ & 36.9 & $x^{* *}$ & $\mathrm{x}$ & $\mathrm{x}$ & 61.7 \\
\hline Cantabria* & $\mathrm{x}$ & & $\mathrm{x}$ & 6.6 & $\mathrm{x}$ & $\mathrm{x}$ & $\mathrm{x}$ & 79.8 \\
\hline
\end{tabular}

(Note) $*=$ Objective 1 regions defined in the framework of the EU Regional Development Programs 2000 2006; ** = Mainly SME-specific promotion; $* * *=$ EU contribution + national contribution (Source) European Commission.

\section{Empirical Analysis}

\section{A. Data and Descriptive Statistics}

In this section, we aim at taking a closer look at the determinants of innovation promotion (in shares and levels) to test whether the descriptive pattern found in the isolated inspection above also shows up in a multivariate analysis. For this purpose, we use various explanatory vari- 
ables. These variables are measured at the level of regional entities and are taken from different sources (see Table 1A in the Appendices for further information on data sources), including a study by the European Parliament (see European Parliament, 2007), the EU Regio database, and the European Regional Innovation Scoreboard (see Hollanders, 2006).

Against the background of the goals of the Lisbon Agenda, innovation is particularly important in the case of regions lagging in economic development. Hence, whether a region is already an innovative region or not should be an important aspect. We take this into account by using the variable RIS. This variable is measured such that a high score on the Regional Innovation Scoreboard (RIS) is associated with enhanced performance in terms of innovation. The composite indicator comprises various aspects as, for example, business and public R\&D expenditures, employment in high-tech manufacturing and service sectors, as well as patent statistics. A priori, we would expect more intensive innovation promotion in the context of the EU cohesion policy in those regions with a lower RIS value.

A standard measure applied by the EU to classify regions according to economic development is the regional GDP per capita (expressed in terms of PPS). If regions consistently pursue the goals of the Lisbon Agenda, regions with low GDP per capita should, ceteris paribus, spend a higher share of their national and EU funds on innovation projects in order to achieve economic catching-up. Moreover, we would also expect that a higher absolute level of innovation promotion is provided to less-developed regions.

Further variables of interest are measures that proxy for features of the local labor market. As one assumption of the new EU cohesion policy is that spending on innovation leads to greater growth and job creation than other forms of spending, it intends to support regions with structural difficulties. Potentially relevant labor-market variables are the Unemployment ratio and the Long-term unemployment ratio. The variable for the long-term unemployed refers to the long-term-unemployment-to-total-employment ratio. A high ratio implies that the region is suffering from serious structural problems. Such structural weakness, in turn, is a typical economic characteristic of lagging regions in the EU. As a consequence, if long-term unemployment is high, a region should more strongly focus on projects that promote innovation in order to overcome such economic difficulties as soon as possible. A similar argument can also be made in the case of the unemployment ratio, which we expect to positively relate to the share of innovation promotion as well as the level of innovation spending. Another appropriate variable that may proxy for labor-market aspects is the share of service sector employment, i.e., employment in the service sector relative to total employment. A high share of employment in the service sector indicates that some structural change ('deindustrialization') has already taken place in a region. For this reason, the service variable is expected to exert a negative effect on innovation promotion.

We further condition on the total local Population and Land area to control for size effects, as well as for Population density to capture differences of spillover effects in urban vs. rural regions. In general, densely populated urban areas are better equipped with innovation systems 
and more successful in terms of innovation. Moreover, we control for a variable that may proxy for the level of development of a region in terms of R\&D and education infrastructure. University accessibility is the share of the regional population that lives within a one hour drive of the nearest university. In addition, the variable GDP accessibility is an indicator of the size of market areas for suppliers of high-order business services, which varies according to the degree of a region's attractiveness as a modern high-tech location. Thus, if the regional policy consequently follows the rule that less-developed regions should be particularly stimulated by providing grants for innovation projects, higher GDP accessibility is expected to negatively relate to innovation promotion. Table 3 provides descriptive statistics for all variables used in our empirical analysis.

Table 3. Descriptive Statistics

\begin{tabular}{l|c|c|c|c}
\hline Variable & Mean & Standard Dev. & Minimum & Maximum \\
\hline Share of innovation spending & 0.282 & 0.239 & 0 & 0.970 \\
Level of innovation spending & 666.299 & 981.347 & 6 & 6,531 \\
\hline Year 2007 & 0.569 & 0.496 & 0 & 1 \\
Objective 1 region & 0.186 & 0.390 & 0 & 1 \\
RIS & 0.595 & 0.297 & 0.070 & 1.600 \\
Ln(GDP per capita) & 9.922 & 0.357 & 8.713 & 11.052 \\
Unemployment ratio & 0.090 & 0.046 & 0.025 & 0.280 \\
Long-term unemployment & 0.402 & 0.134 & 0.130 & 0.679 \\
Employment in service & 0.663 & 0.089 & 0.448 & 0.887 \\
Ln(Land area) & 9.435 & 1.211 & 5.081 & 11.941 \\
Ln(Population) & 7.337 & 0.873 & 4.800 & 9.357 \\
Ln(Population density) & 4.800 & 1.251 & 1.194 & 8.747 \\
University accessibility & 0.704 & 0.230 & 0 & 1 \\
GDP accessibility & 0.966 & 0.967 & 0.022 & 6.363 \\
\hline
\end{tabular}

(Note) 204 observations. If time-varying information is available, variable values refer to the years 1999 and 2006, respectively, depending on the program period. See Table 1A for more details on variable sources and definitions. Level of innovation spending is the amount of total innovation spending provided to a region (measured in 1,000,000 euros). Share of innovation spending is spending on innovation relative to total spending. Year 2007 is a dummy variable with a value of 1 for the program period of 2007 2013, and a value of 0 for the period of 2000 2006. Objective 1 region is a dummy variable taking a value of 1 if a region is classified as an Objective 1 region and 0 otherwise. RIS is an indicator that comprises the overall innovation performance of a region. GDP per capita refers to the regional GDP per capita in PPS. Unemployment ratio is the unemployment rate. Long-term unemployment is the long-term-unemployment-to-total-unemployment ratio. Employment in service is the ratio of employment in the service sector to total employment. Land area is the land area of a re- 
gion measured in square kilometers. Population refers to the total population of a region. Population density is the regional population density measured as inhabitant per square kilometer. University accessibility is defined as the share of the regional population living within a one hour drive of the nearest university. GDP accessibility is an indicator of the size of market areas for suppliers of high-level business services.

(Source) Authors' calculation

\section{B. Results}

Table 4 shows pooled regression results for the 2000 2006 and the 2007 2013 program periods. In this first regression analysis, we investigate the determinants of the share of innovation spending. Since the EU regions are supposed to increase their share of innovation spending in the 2007 2013 period, in column I, we first include the dummy variable Year 2007, which takes a value of 1 if an observation refers to the period of 2007 2013, and 0 otherwise. As expected from Figures 1 and 2 (and also from the descriptive analysis of the Spanish regions), we find that the EU regions place more emphasis on innovation with respect to their funding activities in the period of 2007 2013. The estimated coefficient in column I suggests that the EU has increased the share of innovation spending provided to regions by $21 \%$ compared with the 2000 to 2006 period. Note, however, that this simple bivariate regression neglects other determinants which may have affected the EU's decision process. Since, according to the knowledge-orientation of the Lisbon strategy, we would expect that the increased focus on innovation to be particularly pronounced for the Objective 1 regions, we further include the interaction term (Year 2007)*(Objective 1 region) and a dummy variable indicating Objective 1 regions in column II.

While this specification shows that the share of innovation spending is significantly lower in Objective 1 regions, the coefficient for the interaction term is insignificant, suggesting that there has not been a redistribution of innovation funds towards Objective 1 regions as of the recent program period. This is surprising since, for the earlier EU cohesion program 2000 2006, innovation promotion was not a priority policy issue, but instead regions were to focus on infrastructure and education projects.

In order to investigate further aspects that might have an impact on the share of innovation promotion, the specification in column III includes the indicator RIS, capturing the innovation potential of a region as one major determinant of the share of innovation. If the primary goal of the EU cohesion policy was redistribution, we would expect RIS to have a negative impact, because regions with already advanced innovation performance tend to require less funds for innovation projects relative to other projects promoted in the context of the EU cohesion policy. The estimated coefficient, however, points at a positive relationship. But, when adding 9 more control variables to specification IV, RIS becomes insignificant. 
Table 4. Regression Results - Share of Innovation Spending

\begin{tabular}{|c|c|c|c|c|}
\hline & I & II & III & IV \\
\hline Year 2007 & $\begin{array}{c}0.210^{* * *} \\
{[0.049]}\end{array}$ & $\begin{array}{c}0.208^{* * *} \\
{[0.063]}\end{array}$ & $\begin{array}{c}0.302 * * * \\
{[0.040]}\end{array}$ & $\begin{array}{c}0.112 \\
{[0.083]}\end{array}$ \\
\hline Objective 1 region & & $\begin{array}{c}-0.138^{* *} \\
{[0.052]}\end{array}$ & $\begin{array}{c}-0.107 * * * \\
{[0.035]}\end{array}$ & $\begin{array}{c}-0.084 * * \\
{[0.035]}\end{array}$ \\
\hline $2007 *$ Objective 1 region & & $\begin{array}{c}0.030 \\
{[0.061]}\end{array}$ & $\begin{array}{c}0.027 \\
{[0.057]}\end{array}$ & $\begin{array}{c}0.013 \\
{[0.066]}\end{array}$ \\
\hline RIS & & & $\begin{array}{c}0.227 * * * \\
{[0.063]}\end{array}$ & $\begin{array}{l}-0.070 \\
{[0.077]}\end{array}$ \\
\hline Ln(GDP per capita) & & & & $\begin{array}{l}0.178^{* *} \\
{[0.073]}\end{array}$ \\
\hline Unemployment ratio & & & & $\begin{array}{c}0.080 \\
{[0.430]}\end{array}$ \\
\hline Long-term unemployment & & & & $\begin{array}{c}-0.625 * * * \\
{[0.174]}\end{array}$ \\
\hline Employment in service & & & & $\begin{array}{r}-0.120 \\
{[0.325]}\end{array}$ \\
\hline Ln(Land area) & & & & $\begin{array}{l}1.368^{*} \\
{[0.785]}\end{array}$ \\
\hline Ln(Population) & & & & $\begin{array}{l}-1.363^{*} \\
{[0.773]}\end{array}$ \\
\hline Ln(Population density) & & & & $\begin{array}{c}1.365^{*} \\
{[0.782]}\end{array}$ \\
\hline University accessibility & & & & $\begin{array}{c}0.147 * * \\
{[0.056]}\end{array}$ \\
\hline GDP accessibility & & & & $\begin{array}{l}-0.005 \\
{[0.014]}\end{array}$ \\
\hline $\begin{array}{l}\text { Observations } \\
\text { R-squared }\end{array}$ & $\begin{array}{c}204 \\
0.191\end{array}$ & $\begin{array}{c}204 \\
0.230\end{array}$ & $\begin{array}{c}204 \\
0.269\end{array}$ & $\begin{array}{c}204 \\
0.455\end{array}$ \\
\hline
\end{tabular}

(Note) Pooled OLS estimation, including an intercept (not reported). Dependent variable: share of innovation spending. Robust standard errors (clustered by country) in brackets. If available, all control variables refer to 1999 and 2006 values (see Table 1A for further definitions of control variables).

$*$ significant at $10 \%$; ** significant at $5 \%$; *** significant at $1 \%$.

(Source) Authors' calculation.

Column IV shows that some additionally considered variables are significantly related to the share of innovation spending. First, a higher regional GDP per capita increases the share of innovation promotion. Hence, as there appears to be a comparatively greater need for innova- 
tion spending in less-developed regions, this finding seems to contradict the EU's policy goals of promoting growth by particularly supporting innovative projects in less-favored regions. Furthermore, a higher share of long-term unemployment is associated with a lower share of innovation spending and a higher degree of university accessibility is associated with more innovation promotion relative to total promotion. These two findings support the hypothesis that regions which are already economically advanced obtain a relatively higher share of innovation spending. This clearly violates the a priori expectation that the need for innovation promotion tends to be particularly high in regions where long-term unemployment is high and university accessibility is poor. Finally, the findings for university accessibility and population density suggest that core regions are particularly supported.

However, most importantly, the analysis presented in Table 4 (column IV) shows that, when conditioning on a number of determinants that capture various characteristics of a region, the share of innovation for the 2007 program period has not been increased for the average region and, besides, it has not been increased for the average (less-developed) Objective 1 region. In this sense, investigations relying on simple correlations as Figures 1 and 2, as well as columns I to III, may be misleading.

Of course, while considering variation in many determinants, the EU may have pursued a constant share of innovation spending across regions and over the two program periods, but, at the same time, may have provided more funds in absolute values. For this reason, we use the same regression framework to investigate the level of innovation spending, rather than the share, to learn more about the EU's financing policy. One obvious result from the analysis shown in Table 5 is that the level of innovation financing is, as expected, higher in Objective 1 regions. If the EU's regional policy is particularly aimed at supporting innovation projects in these regions during the second (2007 2013) program period, we would expect that the interaction term $($ Year 2007)*(Objective 1 region) shows a positive coefficient. In fact, though not statistically significant, we estimate a negative relationship. This is rather surprising, because it implies that there has been no major shift in funding strategy, which confirms the findings shown in Table 4. The same is true also for the dummy variable Year 2007 indicating that, ceteris paribus, the 2007 2013 program does not differ from the 2000 2006 program with respect to the level of innovation spending. Concerning other determinants, specification IV shows that more financing is provided to less-developed regions, i.e. the variables $R I S, \operatorname{Ln}(G D P$ per capita), and GDP accessibility are negatively related to the total funds provided for innovation projects. Although this is in line with the basic policy goals of the EU's cohesion policy, the main conclusion from the regression analysis in Table 5 is that, ceteris paribus, there has not been a considerable realignment of the EU's policy towards more innovation funding. 
Table 5. Regression Results - Level of Innovation Spending

\begin{tabular}{|c|c|c|c|c|}
\hline & I & II & III & IV \\
\hline Year 2007 & $\begin{array}{c}85.539 \\
{[132.473]}\end{array}$ & $\begin{array}{c}136.641 \\
{[122.907]}\end{array}$ & $\begin{array}{c}-186.877 \\
{[113.883]}\end{array}$ & $\begin{array}{c}-95.356 \\
{[155.408]}\end{array}$ \\
\hline Objective 1 region & & $\begin{array}{c}1,531.129 * * * \\
{[487.088]}\end{array}$ & $\begin{array}{c}1,425.329 * * * \\
{[442.751]}\end{array}$ & $\begin{array}{c}1,163.800 * * * \\
{[262.214]}\end{array}$ \\
\hline 2007*Objective 1 region & & $\begin{array}{c}-472.571 \\
{[372.257]}\end{array}$ & $\begin{array}{c}-463.642 \\
{[326.640]}\end{array}$ & $\begin{array}{c}-368.395 \\
{[295.780]}\end{array}$ \\
\hline$R I S$ & & & $\begin{array}{c}-781.826 * * * \\
{[232.248]}\end{array}$ & $\begin{array}{c}-576.792 * \\
{[297.465]}\end{array}$ \\
\hline $\operatorname{Ln}(G D P$ per capita $)$ & & & & $\begin{array}{c}-670.515^{* *} \\
{[274.928]}\end{array}$ \\
\hline Unemployment ratio & & & & $\begin{array}{l}-1,210.380 \\
{[2,629.004]}\end{array}$ \\
\hline Long-term unemployment & & & & $\begin{array}{c}620.006 \\
{[905.594]}\end{array}$ \\
\hline Employment in service & & & & $\begin{array}{c}801.575 \\
{[965.487]}\end{array}$ \\
\hline $\operatorname{Ln}($ Land area $)$ & & & & $\begin{array}{c}3,330.340 \\
{[2,501.691]}\end{array}$ \\
\hline Ln(Population) & & & & $\begin{array}{l}-2,898.776 \\
{[2,489.096]}\end{array}$ \\
\hline Ln(Population density) & & & & $\begin{array}{c}3,446.099 \\
{[2,494.188]}\end{array}$ \\
\hline University accessibility & & & & $\begin{array}{c}-373.814 \\
{[259.777]}\end{array}$ \\
\hline GDP accessibility & & & & $\begin{array}{c}-162.213^{* * *} \\
{[37.980]}\end{array}$ \\
\hline $\begin{array}{l}\text { Observations } \\
\text { R-squared }\end{array}$ & $\begin{array}{c}204 \\
0.002\end{array}$ & $\begin{array}{c}204 \\
0.257\end{array}$ & $\begin{array}{c}204 \\
0.284\end{array}$ & $\begin{array}{c}204 \\
0.536\end{array}$ \\
\hline
\end{tabular}

(Note) Pooled OLS estimation, including an intercept (not reported). Dependent variable: level of innovation spending. Robust standard errors (clustered by country) in brackets. If available, all control variables refer to 1999 and 2006 values (see Table A1 for further definitions of control variables).

* significant at $10 \%$; ** significant at $5 \%$; ** significant at $1 \%$.

(Source) Authors' calculation. 


\section{Conclusion}

The integration of the Lisbon strategy into the EU cohesion policy has created some tensions between competitiveness aims and cohesion aspirations. The twin objectives of enhancing competitiveness in the global context and economic and social convergence among European regions are contradictory and inherently comprise different policy options. The so-called innovation trap tends to occur when making relevant EU policy intervention, which results from the apparent contradiction between the comparatively greater need to spend on innovation in lagging regions and their relatively lower capacity to absorb public funds earmarked for the promotion of innovation and to invest in innovation-related activities, compared to more advanced regions.

This study questions the consistency between the cohesion policy's objectives and its practice. The empirical findings of this study show that there has not been a significant change in financing practice. We would have expected such a change according to the new orientation of the EU's cohesion policy, which is supposed to place more emphasis on innovation-related promotion. While less-developed regions obtain higher absolute amounts of innovation funds, innovation spending (as a share of total spending as well as in absolute values) has not been increased for the program period of 2007 2013 compared with the earlier period of 2000 2006. Since we would expect that more funds have been allocated to Objective 1 regions - to increase the long-term prospects of benefitting from innovation there - we also investigate whether the later program period features more innovation promotion in these regions. In fact, after conditioning on various other determinants, we find that the extent of innovation spending, measured as the share of innovation spending as well as the level of innovation spending, has not changed significantly for Objective 1 regions.

To conclusively evaluate our findings of no significant change in the EU's regional policy strategy, aiming at new orientation of the EU cohesion policy raises a number of basic questions which need to be addressed first. They include:

a) Is it possible for a region with limited expertise in knowledge creation to take full advantage of new knowledge?

b) Is it sufficient to use dissemination and technology transfer instruments to upgrade those regions with limited capabilities for indigenous knowledge creation?

c) Are there arguments for investment in innovation network systems in less-favored regions to repair structural imbalances in innovation potential? (see also Musyck and Reid, 2007).

Innovation takes time and many innovation efforts prove fruitless. In addition, we are now just at the beginning of a new cohesion policy era. The best one can expect in the short run appears to be the increased and better targeted provision of financial resources to the lagging EU regions in order to help them to enhance their absorptive capacities of knowledge - the ability of a firm to recognize the value of new, external information, assimilate it and apply it 
to commercial ends - at least to keep up with developments elsewhere (see also De Bruijn and Lagendijk, 2005). To evaluate whether EU cohesion policy has successfully improved the absorptive capacity of knowledge in the less-favored regions remains an important task for future research.

Received 11 January 2012, Revised 9 October 2012, Accepted 20 October 2012

\section{References}

Amin, A. and N. Thrift (1994), Neo-Marshallian Nodes in Global Networks, in: Krumbein, W. (ed.), Ökonomische und politische Netzwerke in der Region, Münster et al.: LIT Verlag, 115-139.

Asheim, B.T. and A. Isaksen (2002), Regional Innovation Systems: The Integration of 'Sticky' and Global 'Ubiquitous' Knowledge, The Journal of Technology Transfer 27, 77-86.

Belussi, F. (2001), The Italian System of Innovation: The Gradual Transition from a Weak "Mission-oriented" System to a Regionalised Learning System, University of Padua, mimeo.

Braczyk, H.J. and M. Heidenreich (1998), Regional Governance Structures in a Globalized World, in: Braczyk, H.J., P. Cooke and M. Heidenreich (eds.), Regional Innovation Systems - The Role of Governance in a Globalized World, London: Routledge, 414-440.

Camagni, R. (ed., 1991), Innovation Networks: Spatial Perspectives, London: Belhaven Press.

Cooke, P. (2001), From Technopoles to Regional Innovation Systems: The Evolution of Localised Technology Development Policy, Canadian Journal of Regional Science 24, 21-40.

Cooke, P. and O. Memedovic (2003), Strategies for Regional Innovation Systems: Learning Transfer and Applications, Vienna: United Nations Industrial Development Organization (UNIDO).

Cooke, P. and K. Morgan (1998), The Associational Economy: Firms, Regions and Innovation, Oxford: Oxford University Press.

Courchene, T. (1995), Glocalization: The Regional/International Interface, Canadian Journal of Regional Science 18, 1-20.

De Bruijn, P. and A. Lagendijk (2005), Regional Innovation Systems in the Lisbon Strategy, European Planning Studies 13, 1153-1172.

De Propris (2007), EU Clusters and Competitiveness Policy, Policy Studies 28, 327-345.

European Commission (2004), Working for the Regions, EU Regional Policy 2000-2006, Luxembourg: Office for Official Publication of the European Communities.

European Commission (2008), Working for the Regions, EU Regional Policy 2007-2013, Brussels, http:// ec.europa.eu/regional_policy/sources/docgener/presenta/working2008/work_en.pdf.

European Parliament (2007), Regional Disparities and Cohesion: What Strategies for the Future?, Brussels, https://www.europarl.eu/activities/expert/eStudies.do?language=EN.

Fagerberg, J. and M. Srholec (2007), The Role of “Capabilities” in Development: Why Some Countries Man- 
age to Catch Up While Others Stay Poor, DIME Working paper 2007.08, University of Oslo.

Fritsch, M. (2001), Co-operation in Regional Innovation Systems, Regional Studies 35, 297-307.

Fromfold-Eisebith, M. (2007), Bridging Scales in Innovation Policies: How to Link Regional, National and International Innovation Systems, European Planning Studies 15, 217-233.

Glaeser, E.L., H.D. Kallal, J.A. Scheinkman and A. Shleifer (1992), Growth in Cities, Journal of Political Economy 100, 1126-1152.

Grabher, G. and D. Stark (1997), Organizing Diversity: Evolutionary Theory, Network Analysis and Postsocialism, Regional Studies 31, 533-544.

Grossmann, G. and E. Helpmann (1991), Innovation and Growth in the Global Economy, Cambridge: MIT Press.

Grotz, R. and B. Braun (1997), Territorial or Trans-territorial Networking: Spatial Aspects of Technologyoriented Cooperation within the German Mechanical Engineering Industry, Regional Studies 31, 545-557.

Gray, C. (1992), Growth Orientation and the Small Firm, in: Caley, K., E. Chell, F. Chittendon and C. Mason (eds.), Small Enterprise Development, London: Sage Publications, 59-71.

Heidenreich, M. (2003), The Dilemmas of Regional Innovation Systems, in: Braczyk, H.J., P. Cooke and M. Heidenreich (eds.), Regional Innovation Systems - The Role of Governance in a Globalized World, London: Routledge, 497-538.

Hoekman, J., K. Frenken and F.G. van Oort (2009), The Geography of Collaborative Knowledge Production in Europe, Annals of Regional Science 43, 721-738.

Hollanders, H. (2006), 2006 European Regional Innovation Scoreboard (2006 RIS), MERIT - Maastricht Economic and Social Research and Training Centre on Innovation and Technology, Maastricht, www.proinnoeurope.eu/.../Scoreboard2006/.../eis_2006_regional_innovation_scoreboard.pdf.

Ingiani, A. and V. Zdarek (2009), Real Convergence in the New Member States: Myth or Reality?, Journal of Economic Integration 24, 294-320.

Karlsson, G. (1995), Innovation Adoption, Innovation Network and Agglomeration Economies, in: Bertuglia, C.S., M.M. Fischer and G. Preto, Technological Change, Economic Development and Space, Berlin et al.: Springer, 184-207.

Karras, G. (1997), Economic Integration and Convergence: Lessons from Asia, Europe and Latin America, Journal of Economic Integration 12, 419-432.

Koschatzky, K. and M. Gundrum (1997), Innovation Networks for Small Enterprises, in: Koschatzky, K. (ed.), Technology-Based Firms in the Innovation Process. Management, Financing and Regional Networks, Heidelberg: Physica-Verlag, 203-224.

Lawton-Smith, H. (2003), Knowledge Organizations and Local Economic Development: The Cases of Oxford and Grenoble, Regional Studies 37, 899-909.

Leonardi, R. (2006), The Impact and Added Value of Cohesion Policy, Regional Studies 40, 155-166.

Maurseth, P.B. and B. Verspagen (2002), Knowledge Spillovers in Europe: A Patent Citations Analysis, Scandinavian Journal of Economics 104, 531-545.

Melloni, N. and G. Palmieri (2011), How to Develop the Periphery?: The Regional Integration Case of BassoFerrarese in Italy, Journal of Economic Integration 26, 477-498. 
Mills, E.S. and J.F. McDonald (1992), Sources of Metropolitan Growth, New Brunswick NJ: Center for Urban Policy Research, Rutgers University.

Musyck and Reid (2007), Innovation and Regional Development, Do European Structural Funds make a Difference?, European Planning Studies 15, 961-983.

Nam, C.W. and G. Wamser (2011), Application of Regionally Varying Co-financing Degrees in the Practice of EU Cohesion Policy, CESifo Forum 12(4), 57-67.

Nauwelaers, C. and R. Wintjes (2000), SME Policy and the Regional Dimension of Innovation: Towards a New Paradigm for Innovation Policy?, MERIT-University of Maastricht, Maastricht, mimeo.

Nelson, R. (ed. 1993), National Innovation System, New York: Oxford University Press.

Pavitt, K., M. Robson and J. Townsend (1987), The Size of Distribution of Innovating Firms in the UK: 19451983, Journal of Industrial Economics 35, 297-316.

Piore, M. and C.F. Sabel (1984), The Second Industrial Divide. Possibilities for Prosperity, New York: Basic Books.

Puttnam, R. (1993), Making Democracy Work: Civic Traditions in Modern Italy, Princeton: Princeton University Press.

Rothwell, R. (1986), The Role of Small Firms in Technological Innovation, in: Curran, J., J. Stanworth and D. Watkins (eds.), The Survival of Small Firms, London: Ashgate, 114-139.

Schumpeter, J.A. (1934), The Theory of Economic Development, Cambridge: Harvard University Press.

Sternberg, R. (1995), Technologiepolitik und High-tech Regionen - ein internationaler Vergleich, Münster: LIT Verlag.

Turpin, T. and S. Garrett-Jones (2002), Conclusion: Intersecting Systems of Innovation, in: Turpin, T., L. Xielin, S. Garrett-Jones and P. Burns (eds.), Innovation, Technology Policy and Regional Development, Cheltenham and Northampton: Edward Elgar, 193-213.

Wiig, H. and H. Wood (1997), What Comprises a Regional Innovation System? -Theoretical Base and Indicators, in: Simmie, J. (ed.), Innovation, Networks and Learning Regions?, London et al.: Jessica Kingsley Publishers, 66-100.

Wolfe, D. (2002), Social Capital and Cluster Development in Learning Regions, in: Holbrook, J.A. and D. Wolfe (eds.), Knowledge, Clusters and Regional Innovation: Economic Development in Canada, Kingston: School of Policy Studies, Queen's University, 11-38.

Wynarczyk, P., A. Thwaites and P. Wynarczyk (1997), The Financial and Entrepreneurial Characteristics of Innovative Small Firms in Contrasting Regional Environments of the UK, in: Simmie, J. (ed.), Innovation, Networks and Learning Regions?, London et al.: Jessica Kingsley Publishers, 32-50.

Yin, L. and G.K. Zestos (2003), Economic Convergence in the European Union, Journal of Economic Integration 18, 188-213.

Yoon, S.C. (2004), Economic Integration with Endogenous Technological Change in Knowledge-based Services: A New Economy, Journal of Economic Integration 19, 53-78.

Zhang, W.B. (2007), Growth and Agglomeration of a Small-Open Multi-Regional Economy, Journal of Economic Integration 22, 515-542. 


\section{Appendices}

Table 1A: Variable Description and Data Sources

\begin{tabular}{|l|l|l|}
\hline \multicolumn{1}{|c|}{ Variable } & \multicolumn{1}{|c|}{ Description } & \multicolumn{1}{c|}{ Database } \\
\hline $\begin{array}{l}\text { Share of innovation } \\
\text { spending }\end{array}$ & $\begin{array}{l}\text { Innovation supporting funds provided by the } \\
\text { national government and the EU relative to total } \\
\text { expenditures for the respective budget period }\end{array}$ & $\begin{array}{l}\text { EU regional program } \\
\text { 2000 2006, 2007 2013 }\end{array}$ \\
\hline $\begin{array}{l}\text { Level of innovation } \\
\text { spending }\end{array}$ & $\begin{array}{l}\text { Innovation supporting funds provided by the } \\
\text { national government and the EU }\end{array}$ & $\begin{array}{l}\text { EU regional program } \\
\text { 2000 2006, 2007 2013 }\end{array}$ \\
\hline $\begin{array}{l}\text { RIS (Regional } \\
\text { Innovation Scoreboard) } \\
\text { 2006* }\end{array}$ & $\begin{array}{l}\text { A re-scaled synthetic indicator showing the } \\
\text { overall innovation performance of regions in } \\
\text { the EU }\end{array}$ & Hollanders (2006) \\
\hline GDP per capita & $\begin{array}{l}\text { Regional GDP per capita (in PPS); yearly } \\
\text { data 1999 2006 }\end{array}$ & EU Regio database \\
\hline Unemployment ratio & Unemployment rate 1999 2006 & EU Regio database \\
\hline $\begin{array}{l}\text { Long-term } \\
\text { unemployment }\end{array}$ & $\begin{array}{l}\text { Long-term unemployment in 2005 as a share } \\
\text { of total unemployed persons }\end{array}$ & EU Regio database \\
\hline Employment in service & $\begin{array}{l}\text { Employment in the service sector relative to } \\
\text { total employment in 2005 }\end{array}$ & EU Regio database \\
\hline Land area & Land area in square kilometer & EU Regio database \\
\hline Population & Total population of a region & EU Regio database \\
\hline Population density & $\begin{array}{l}\text { Regional population density measured as } \\
\text { inhabitant per square kilometer (1999 2006) }\end{array}$ & EU Regio database \\
\hline University accessibility & $\begin{array}{l}\text { Share of regional population living within a } \\
\text { one hour drive of the nearest university }\end{array}$ & $\begin{array}{l}\text { Study of the European } \\
\text { Parliament (2007) }\end{array}$ \\
\hline GDP accessibility** & $\begin{array}{l}\text { An indicator of the size of market areas for } \\
\text { suppliers of high-level business services, } \\
\text { standardized at EU27+2*** }\end{array}$ & $\begin{array}{l}\text { Study of the European } \\
\text { Parliament (2007) }\end{array}$ \\
\hline
\end{tabular}

(Note) * The RIS 2006 is calculated based on a set of seven determinants, capturing human resource and knowledge creation indicators from different statistical sources such as labor force survey, R\&D statistics, and patent statistics. These seven determinants include: (1) human resources in science and technology - core (\% of population in 2004), (2) participation in life-long learning (\% of 25 64 years age class in 2004), (3) employment in medium-high and high-tech manufacturing (\% of total workforce in 2004), (4) employment in hightech services (\% of total employment in 2004), (5) public R\&D expenditures (total R\&D expenditures - business expenditures on R\&D) (\% of GDP in 2002), (6) business expenditures on R\&D (\% of GDP in 2002), and (7) The European Patent Office (EPO) patent applications (per million population in 2002).

** Potential accessibility is measured based on the assumption that the attraction of a destination increases with size, and declines with distance, travel time, or cost. Destination size is usually represented by GDP or population. In other words, potential accessibility is a construct of two functions, the activity function representing the activities or opportunities to be reached and the impedance function representing the effort, time, distance, or cost needed to reach them. For potential accessibility the two functions are combined multiplicatively.

*** Switzerland and Norway. 